\title{
Affectivity and physical habits in adolescents: A systematic review
}

\author{
Afectividad y hábitos físicos en adolescentes: una revisión sistemática \\ Álvaro Cristian Huerta-Ojeda1,2* orcid.org/0000-0001-6871-098X \\ Gerardo Riquelme-Vera' ${ }^{1}$ orcid.org/0000-0003-0603-1222 \\ María Mercedes Yeomans-Cabrera ${ }^{2}$ orcid.org/0000-0003-2138-3007
}

1. Grupo de Investigación en Salud, Actividad Física y Deporte ISAFYD, Universidad de Las Américas sede Viña del Mar, Chile

2. Facultad de Educación, Universidad de Las Américas, sede Viña del Mar, Chile

\section{Resumen}

Introducción: La afectividad tiene un papel fundamental dentro del proceso de formación en los sistemas educativos. Sin embargo, no existen estudios actualizados que evidencien los diversos agentes socioafectivos utilizados en la creación de hábitos físicos en la población infantil y adolescente de los sistemas escolares. Objetivo: Analizar investigaciones previamente publicadas que estudiaron la influencia de la afectividad en los hábitos físicos de niños y adolescente de los sistemas escolares. Materiales y métodos: El estudio corresponde a una revisión sistemática. Se evaluaron artículos publicados entre 2010 y 2020 que relacionaron afectividad y hábitos físicos. La búsqueda electrónica se realizó a través de las bases Web of Science, Scopus y Scielo. Se incluyeron todos los artículos que utilizaron la afectividad sobre los hábitos físicos de la población. Resultados: Se encontraron tres artículos que utilizaron la afectividad sobre los hábitos físicos de niños y adolescentes. Conclusiones: Al término de la revisión sistemática, se demostró que existe una tremenda influencia entre la afectividad y los hábitos físicos de la población infantil y adolescente. También se pudo observar que esta influencia, positiva o negativa, condiciona el interés de la población infantil y juvenil por la actividad física y el deporte en la vida adulta.

Palabras clave: Crecimiento y desarrollo; educación; psicología; complicaciones; clasificación. (Fuente: DeCS, Bireme).

\begin{abstract}
Introduction: Affectivity has a fundamental role in educational systems' training process. However, there are no updated studies that show the different socio-affective agents used in the creation of physical habits in the child and adolescent population in school systems. Objective: To review and analyze previously published research that studied the influence of affectivity on children and adolescents' physical habits in school systems. Materials and methods: A systematic review was conducted with articles published between 2010 and 2020, which connected affectivity and physical habits. The electronic search was performed through Web of Science, Scopus, and Scielo databases. All articles that studied the influence of affectivity on the population's physical habits were included. Results: Three studies that analyzed the influence of affectivity on children and adolescents' physical habits were found. Conclusions: At the end of the systematic review, it was demonstrated that there is a significant relationship between affectivity and the physical habits in child and adolescent populations. It was also possible to observe that this influence, positive or negative, determines the child and adolescent population's interest in physical activity and sports in adult life.
\end{abstract}

Key words: Growth and development; education; psychology; complications; classification. (Source: DeCS, Bireme).

\footnotetext{
* Corresponding author at: Álvaro Cristian Huerta Ojeda e-mail: achuertao@yahoo.es
} 


\section{Introduction}

The acquisition of a better quality of life results from several factors, such as the food system, social and cultural norms, and family environment. Some factors involve regulatory and commercial aspects that shape the food system and define the availability and accessibility of food(1). In this sense, a significant relationship between consumption of ultraprocessed food and weight, body mass index (BMI), and the abdominal perimeter has been evidenced(2). Another factor that conditions the quality of life is the social and cultural norms concerning physical activity, including the built environment in cities; these environments typically restrict physical activity possibilities ${ }^{(1)}$.

Indeed, a study by Álvarez et al.(3), concluded that people's perception is that the environments, due to environmental barriers, do not favor the practice of physical activity. Besides, avoiding low energy-cost activities, such as spending a long time sitting, should be recommended for the population's physical activity guidelines( ${ }^{(4)}$. In addition to the factors already mentioned, the family environment is another variable that conditions a good quality of life. In this sense, the family plays a fundamental role as a model in the formation of the individual(5). The last two factors (socio-cultural norms and family environment) may condition the population's quality of life and lead to high sedentarism levels. This latter condition increases cardiovascular and metabolic risk factors ${ }^{(4)}$.

In Chile, levels of sedentary lifestyles are above $80 \%$ in most age ranges; it ranks second among the countries with the highest prevalence of obesity $(6,7)$. Furthermore, it has been estimated that $34.4 \%$ of the population over the age of 15 is obese ${ }^{(8)}$. Likewise, some studies have estimated that by 2030 deaths attributed to obesity will exceed 200,000 and life expectancy will decrease ${ }^{(9)}$. These facts are the reason why the educational community and the social environment of children and adolescents must make a great effort to create and promote physical activity habits as soon as possible; thus, there will be a greater probability of generating an active life in adulthood(10). In addition to the physical benefits of physical activity during childhood, there are also economic aspects that benefit from this practice; a sedentary and obese population represents a high economic burden for the individual and society(9). In addition, physical activity has been shown to bring socioemotional benefits, which could turn into positive physical habits. If these positive effects are experienced during childhood and youth, the individual will continue a healthy lifestyle into adulthood(11).

To achieve an active and healthy life, the World Health Organization declared that children and young people from 5 to 17 years old should spend at least 60 minutes a day in moderate to vigorous physical activity; besides, more time investment will bring more significant health benefits(12). However, it has been shown that over $86 \%$ of the population in Chile does not engage in regular physical activity; this proportion is even higher among women and people of lower socioeconomic status(13). Also, most populations have a low energy expenditure in their work-related activities(14); besides, most of the population, especially children, spend two or more hours a day watching television or playing video or computer games(15).

Therefore, parents play a very relevant role in this stage since they are considered the first influencers for young people(16). In this sense, some studies have shown that there is a strong relationship between the physical activity developed by parents and the acquisition of physical activity habits by their sons and daughters; more specifically, adolescents with more physically active parents were more physically active than peers with less physically active parents(17). Similar results have been found concerning the influence of coaches' behavior on athletes (aspects such as athletes' well-being(18), and abandonment of the sport)(19). Therefore, a study by Sánchez et al.(20), concluded that amusement during practice generates more adherence to sports, and decrease premature sport abandonment. Likewise, intrinsic motivation in the practice of physical exercise is a crucial factor to ensure active participation in physical habits(21), producing more opportunities for socialization and greater psychological and physical well-being in people.

The influence of the affectivity of the environment on adolescents' physical habits is fundamental, especially at development ages(22). It is very important that adolescents know how to react to the feelings and emotions of their age ${ }^{(23)}$. Besides, there is a positive relationship between the practice of physical activity in a child and the perceived positive emotional effects; this positive relationship is evidenced in improved self-esteem, reduced anxiety, and stress(24). To this end, the aim is to reinforce the child's positive attributes and diminish the negative 
ones, knowing first the children's emotions, taking into account various socio-environmental factors ${ }^{(25)}$.

Within these socio-environmental factors, we can mention the work of self-confidence and self-efficacy in children and adolescents, being these fundamental aspects to carry out successfully a task ${ }^{(26)}$. Activities of this style will allow to work and to act in specific emotional scenarios of the adolescent, such as: not to ignore its feelings and emotions; to maintain a constant enthusiasm to carry out activities; and to control and to know how to handle states of unhappiness and sadness, situations of lack of interest, discouragement, and boredom(27).

Over the last decades, the number of children and adolescents with obesity has increased tenfold worldwide, and $60 \%$ of the world's population is not physically active enough to obtain health benefits(12). Thus, physical inactivity and obesity have been declared a worldwide epidemic (28). As a result of this, generating physical habits in adolescence is vital to generate an awareness of this problem(29).

Simultaneously, it has been demonstrated that an adequate support system together with social connection with the adolescent favors the experience of positive affective states. This creates a better emotional management in the individual, contributing to their self-confidence and selfefficacy(30). It is essential to achieve adherence to physical habits(31) due to the positive correlation between exercise habits in children and adolescents with active adult life ${ }^{(32)}$. Consequently, creating healthy habits is of great importance to reduce sedentarism and obesity; recognizing various social strategies could encourage the development of physical habits and thus improve health(6). However, to the best of our knowledge, there are no up-to-date studies that reliably present the various socioaffective agents that influence the physical habits of the adolescent population. That is why this systematic review's objective was to review and analyze previously published research that studied the influence of affectivity on adolescents' physical habits.

\section{Materials and methods}

The development of this systematic review was carried out through a thorough reference-oriented search in different databases and electronic search engines: Web of Science (WOS), Scopus, and Scielo.
The search limits were articles published between January 2010 and April 2020.

\section{Databases}

The literature search was conducted under the guidelines for systematic reviews and meta-analysis (PRISMA)(33). In each of the databases, the title, abstract, and keyword search fields were searched. The following keywords were used in combination with the Boolean operators AND/OR: (["Affectivity" OR "Affective Behaviour"] AND ["Sport" OR "Recreational Activities"]). Two authors conducted the search and reviewed the studies; both decided whether the inclusion was appropriate.

\section{Inclusion and exclusion criteria}

The studies included in this systematic review were experimental studies published in the last ten years. Each study's importance was evaluated under inclusion criteria regarding their research design in population, intervention, comparator, results, and language. Studies had to be focused on teenage students in the educational system and on affectivity or affective behaviors on adolescents' physical habits.

They also had to compare various sports or recreational activities and approach results from the benefits or disadvantages of affectivity over sports practice in adolescents. Studies had to be published in English, Spanish, French, or Portuguese. The exclusion criteria were editorial documents, expert opinion essays, and papers not related to physical education, school, adolescents, or affectivity. Studies that did not meet the inclusion criteria were not considered in the systematic review. Both the articles' inclusion criteria and the discrepancies found were resolved by consensus between the two researchers who were part of the systematic review.

\section{Results}

The search strategy was divided into five stages. Stage one: electronic search in different databases, identifying 65 articles. After deleting all duplicates (18 articles), 47 articles remained. Stage two: Title and abstract filtering. After deleting articles by the exclusion criteria (41 articles), six articles were left. Stage three: Comprehensive analysis of the six articles. After reviewing the six articles, three were eliminated because they did not meet the inclusion criteria. Stage four: search for articles guided by the bibliography. No new studies were included in this phase. Therefore, the total number of studies for the systematic review was three articles (Figure 1). 


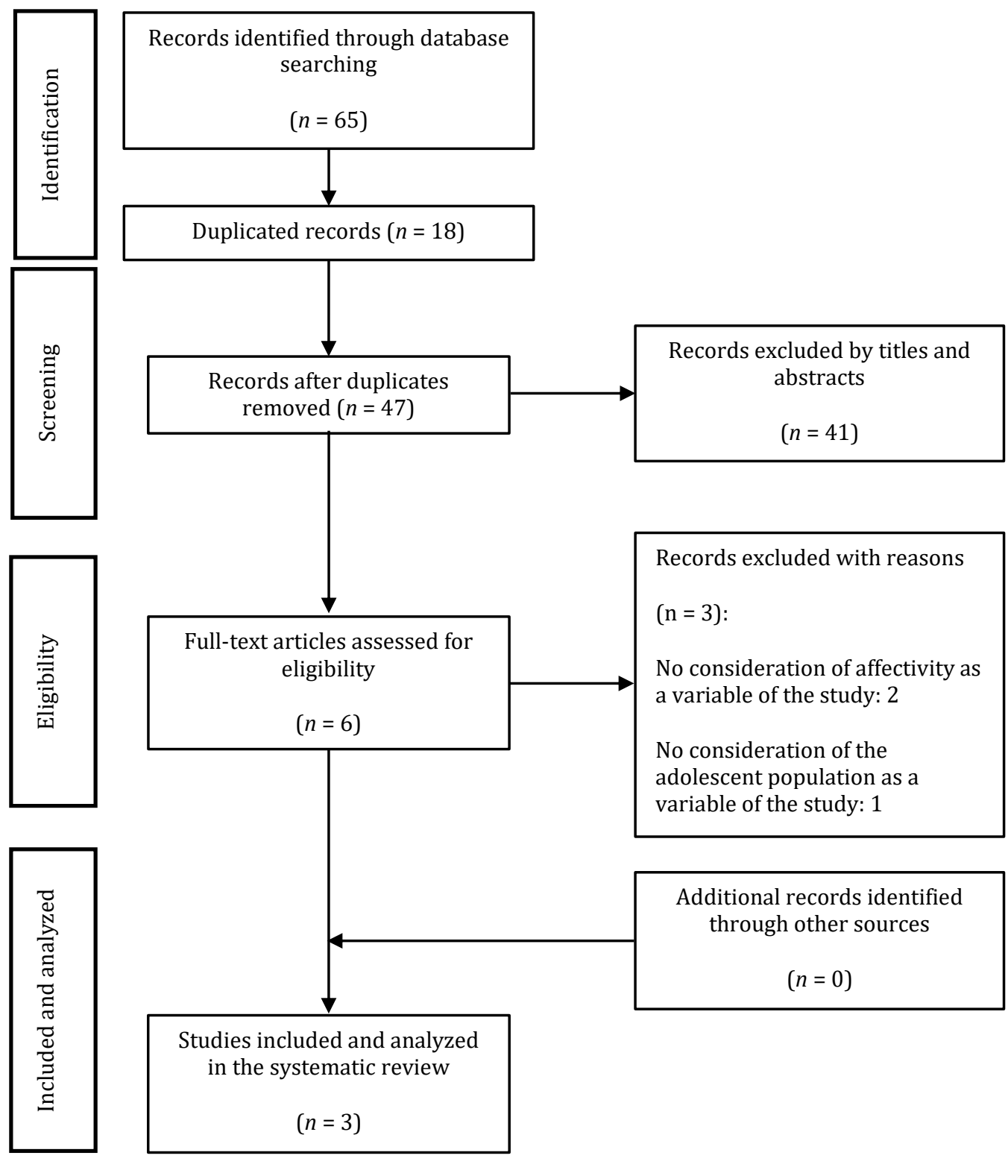

Figure 1. Identification of studies for the svstematic review

The methodological quality of the selected articles

It was used the Physiotherapy Evidence Database (PEDro) scale $(34,35)$ to evaluate the studies' quality. The classification was based on three criteria: selection (maximum three stars), comparability (maximum three stars), and results (maximum four stars). Articles with scores from eight to ten were considered as high methodological quality. Those with scores from four to seven of moderate quality and those with scores below four were considered low quality.
The items on the PEDro scale are 11: (1) eligibility criteria were specified; (2) subjects were randomly allocated to groups; (3) allocation was concealed; (4) the groups were similar at baseline regarding the most important prognostic indicators; (5) there was blinding of all subjects; (6) there was blinding of all therapist that administrated the therapy; (7) there was blinding of all assessors who measured at least one key outcome; (8) measurements of at least one key outcome were obtained from more than $85 \%$ of the subjects initially allocated in groups; (9) all subjects for whom outcome measurements were available received the treatment or control condition 
as allocated, or where this was not the case, data for at least one key outcome were analyszed by "intention to treat"; (10) the results of between-group statistical comparisons are reported for at least one key outcome; (11) the study provides both point measurements and measurements of variability for at least one key outcome ${ }^{(34)}$.

The score obtained by the articles, according to the PEDro scale, indicates that three studies obtained a high score (Table 1).

Within the three selected studies, independent of the type of socio-emotional support, sex, age, body mass index, all three presented significant results in the influence of affectivity $(30,36,37)$ (Table 2).
Table 1. List of items included with scores according to PEDro's scale

\begin{tabular}{|c|c|c|c|c|}
\hline & $\begin{array}{l}\text { Selection } \\
(1-2-3-4)\end{array}$ & $\begin{array}{c}\text { Comparability } \\
(5-6-7)\end{array}$ & $\begin{array}{c}\text { Results } \\
(8-9- \\
10-11)\end{array}$ & Total \\
\hline $\begin{array}{l}\text { Gil- } \\
\text { Madrona et } \\
\text { al. } \\
(2019)^{(37)}\end{array}$ & \#-*_*_* & *_*_* & $*_{-} *_{-} *_{-} *$ & 10 \\
\hline $\begin{array}{l}\text { Molina et } \\
\text { al. } \\
(2018)^{(30)} \\
\text { Méndez- } \\
\text { Giménez et } \\
\text { al. } \\
(2018)^{(36)}\end{array}$ & \#-0-*_* & $*_{-} *_{-} *$ & $*_{-} *_{-} *_{-} *$ & 10 \\
\hline
\end{tabular}

\#: meets the criterion but is not part of the final score of the scale; *: meets the criterion and is part of the final score of the scale; 0: does not meet the criterion.

Table 2. Characteristics of the publications that relate affectivity and sports practice in adolescents

\begin{tabular}{|c|c|c|c|c|c|c|c|}
\hline Reference & Year & Objectives & Subjects & Variables & Protocol & Results & Influence \\
\hline $\begin{array}{l}\text { Gil- } \\
\text { Madrona } \\
\text { et al.(37) }\end{array}$ & 2019 & $\begin{array}{l}\text { To identify and analyze } \\
\text { the positive and negative } \\
\text { affectivity present in } \\
\text { Physical Education } \\
\text { classes and analyze the } \\
\text { relationships or } \\
\text { differences concerning } \\
\text { their BMI. }\end{array}$ & $\begin{array}{l}\text { S:786 } \\
M: 406 \\
W: 380\end{array}$ & $\begin{array}{l}\text { I: AF } \\
\text { D: ES, BMI }\end{array}$ & $\begin{array}{l}\text { Affectivity was } \\
\text { evaluated } \\
\text { through the } \\
\text { PANAS } \\
\text { instrument in } \\
\text { the Spanish } \\
\text { version. }\end{array}$ & $\begin{array}{l}\text { PA: M }(24.54 \pm 3.11) \text { vs W } \\
(24.32 \pm 3.18) \\
\text { NA: M }(15.63 \pm 3.55) \text { vs W } \\
(16.32 \pm 4.01)^{*} \\
\text { PA: wo/O }(24.58 \pm 2.95) \\
\text { vs w/O }(23.77 \pm 3.07)^{*} \\
\text { NA: wo/O }(15.67 \pm 3.89) \\
\text { vs } w / 0(16.14 \pm 4.14)\end{array}$ & $\uparrow$ \\
\hline $\begin{array}{l}\text { Molina et } \\
\text { al.(30) }\end{array}$ & 2018 & $\begin{array}{l}\text { To determine the } \\
\text { influence of socio- } \\
\text { emotional support on } \\
\text { experienced affectivity, } \\
\text { self-confidence, and self- } \\
\text { efficacy in young } \\
\text { athletes. }\end{array}$ & $\begin{array}{l}\text { S: } 300 \\
\text { EG1: IC } \\
\text { EG2: AC } \\
\text { W: } 15.15 \\
\pm 2.38\end{array}$ & $\begin{array}{l}\text { I: Positive } \\
\text { emotions } \\
\text { D: CR, PE, } \\
\text { SC, PS, TA }\end{array}$ & $\begin{array}{l}\text { Application of } \\
\text { questionnaire to } \\
\text { athletes about } \\
\text { affective } \\
\text { balance, } \\
\text { emotional } \\
\text { regulation, the } \\
\text { climate } \\
\text { sports, in } \\
\text { competition, and } \\
\text { parental } \\
\text { support. }\end{array}$ & $\begin{array}{l}\text { Parents support climate } \\
\text { vs. Self-confidence: } r= \\
0.55^{* *} \\
\text { Trainer } \quad \text { vs. Self- } \\
\text { confidence: } r=0.36^{* *}\end{array}$ & $\uparrow$ \\
\hline $\begin{array}{l}\text { Méndez- } \\
\text { Giménez } \\
\text { et al.(36) }\end{array}$ & 2018 & $\begin{array}{l}\text { A) To analyze age and } \\
\text { gender differences in } 3 \times 2 \\
\text { achievement goals, } \\
\text { friendship goals, and } \\
\text { affectivity in the context } \\
\text { of physical education. B) } \\
\text { To study the } \\
\text { relationships between } \\
\text { variables. To explore the } \\
\text { predictive value between } \\
\text { objectives A and B. }\end{array}$ & $\begin{array}{l}\text { S: } 1610 \\
\text { EG1: } 405 \\
(10-12 \\
\text { years) } \\
\text { EG2: } 646 \\
(13-14 \\
\text { years) } \\
\text { EG3: } 559 \\
\text { (15-17 } \\
\text { years) }\end{array}$ & $\begin{array}{l}\text { I: } \\
\text { Friendship } \\
\text { D: positive } \\
\text { and } \\
\text { negative } \\
\text { affectivity }\end{array}$ & $\begin{array}{l}\text { Application of } \\
\text { questionnaire of } \\
\text { goals of } \\
\text { achievement in } \\
\text { Physical } \\
\text { Education and } \\
\text { posterior linear } \\
\text { regression } \\
\text { analysis. }\end{array}$ & $\begin{array}{l}\uparrow \text { PA en EG1 }\left(\mathrm{r}^{2} 0.21\right)^{* * *}- \\
\left.\text { EG3 ( } \mathrm{r}^{2} 0.19\right)^{* *} \text { being the } \\
\text { biggest predictors PA- } \\
\text { task and Ap friendship } \\
\left.\text { and, in EG2 ( } \mathrm{r}^{2} 0.21\right)^{* * *} \\
\text { PA- task and Ev- task. } \\
\left.\uparrow \text { NA en EG1 ( } \mathrm{r}^{2} 0.05\right)^{* *}- \\
\text { EG3 (r2 0.04)* being the } \\
\text { biggest predictors PA- } \\
\text { task and, in EG2 ( }{ }^{2} \\
0.07)^{* *} \text { PA-friendship. }\end{array}$ & $\begin{array}{l}\uparrow \\
\uparrow\end{array}$ \\
\hline
\end{tabular}

S: Students; SC: Self-confidence; TA: Trainer autonomy; AF: Affectivity; NE: Negative Affection; PA: positive affection; AC: Advanced Category; IC: Initial category; PS: Parents support climate; D: Dependent; ES: Emotional states; PE: Perceived effectiveness; EG: Experimental group; M: Men; I: Independent; W: Women; NS: Non significant; CR: Cognitive reassessment; S: Significant; SD: Standard deviation; $\uparrow:$ Influence; $\downarrow$ : No influence. wo/0: without obesity; w/0: with obesity. PANAS: Positive and Negative Affect Schedule; ${ }^{*}$ p $<0.05$; ${ }^{* *}$ : $<0.01{ }^{* * *}$ : $p<0.001$. 


\section{Discussion}

At the end of the systematic review, several affective situations were found to influence adolescents' physical habits(38). These studies focused on analyzing the importance of affectivity for Physical Education classes, as well as the relationship between affectivity and the presence of obesity, gender diversity, and the development of physical habits(22). Simultaneously, it was observed that the correct planning of a Physical Education class could directly influence the students' integral development and generate a greater interest in physical activity. The latter could also increase selfesteem and motivation towards physical habits, decreasing overweight and obesity(37).

Another finding of the systematic review was the influence and stability generated by a correct relationship with the family and the training coach, directly affecting the adolescent's sports adherence and performance(30). Some studies also reported differences in the students' ages and genders, demonstrating different interests and tastes( ${ }^{(36)}$. These findings allow us to observe the influence that affectivity has on the habits of physical activity, physical exercise, and sports, which improve the population's quality of life.

\section{Affectivity as cause and effect}

Affectivity can be analyzed from two different perspectives: as a cause (positive and negative feelings towards physical education classes) and as an effect (positive or negative emotions as a consequence of the class). From a causal standpoint, the most effective learning occurs when learners have positive emotions, are engaged in the class, and are not stressed. Research establishes that information is more likely to be fixed in long-term memory when it is relevant to the learner( ${ }^{(3)}$.

Motivation is another positive feeling towards classes; according to research, its levels are connected to class engagement( ${ }^{(39)}$. Students with intrinsic motivation are authentically engaged to practice learning in behavioral, emotional, and agentic dimensions (40). There is also evidence that other positive feelings, such as character strengths, become crucial for students' school functioning and their overall school achievement ${ }^{(41)}$. On the other hand, negative emotions towards the class have negative learning consequences. Stress prevents the information storage process( ${ }^{(42)}$, which is a feeling that comes from very different sources (conflicts, life changes, pressure, among others) ${ }^{(43)}$. Besides, the lack of motivation decreases as the school level increases (39); therefore, adolescent students become less motivated than children. There are also psychosocial factors involved in student participation; fear, embarrassment, social isolation, judgment, and discrimination are barriers to participation ${ }^{(44)}$.

From the effect perspective, positive emotions that are caused during a class can be very motivating for students. Teachers' instructional practices have shown significant relation to student motivation(45), and students have a positive perception when teachers communicate their feedback verbally(46). Some negative emotions that may arise at school are: anxiety (connected to changes in adolescent school transition (47); self-defense and reduced attention ${ }^{(48)}$; and 'embarrassment evaluation' (loss of self-esteem over task failures) and 'embarrassment as exposure' (individual thinking that others are monitoring them)(49), among others.

Considering that external influence at school may promote positive emotions and that these emotions may predispose students towards a better class outcome, it is recommended that teachers promote a supportive environment for their students. Promoting positive emotions and a supportive school environment will contribute to students' wellbeing(50). It is recommended, from a neuroscientific approach, to: arouse students' curiosity and interest, counteract stress, boredom, and frustration, defuse undesirable behaviors, incorporate motivating goalgame learning (achievable challenges, predictions, and permanent feedback) break through stereotypes, and develop students' executive function skills (such as focus, prioritization, organization, collaboration, critical analysis, and innovation). The brain converts a vast amount of sensory input into long-term memory and durable understanding ${ }^{(42) \text {. }}$

\section{Positive and negative affectivity present in Physical Education classes}

Students show very varied emotions from the cause perspective due to the affective influences present in Physical Education classes; vitality and being physically active are the variables that contribute most to positive affectivity(30). In turn, feelings of stress, fright, shame, and agitation are the most significant negative affectivity, especially in girls $(23,51)$. Contexts for experiences of body-related embarrassment primarily include school and sports or physical activity settings; it connects to fear of negative evaluation, social comparisons, body 
exposure, and inadequacy compared to an internal standard(51). From the effect perspective, to increase positive affectivity, teachers should use these results to design and develop classroom intervention programs, considering the emotional characteristics of students(52). In this way, one could ensure adherence to physical activities and sports practices in the future, consolidating a healthy lifestyle ${ }^{(29)}$. Also, in Physical Education classes, positive feedback has predicted greater intentions to participate ${ }^{(53)}$. In this sense, the tendency is to decrease the adverse effects and increase the positive ones ${ }^{(54,55) .}$

\section{Influence of the coach on the motivation of the athletes}

Some precedents associate greater amusement in the game with greater adherence to sports practice ${ }^{(20)}$. In this regard, the motivational climate created by coaches within youth sports teams is of great importance to the quality of young people's sports experiences(56). Regarding the latter, Ruiz et al.(57) tested a motivational model in the sport context via structural equation modeling. These researchers concluded that the perceived task climate emerged as a positive predictor of satisfaction of all three psychological needs; in contrast, the perceived ego climate was a negative predictor of relationship satisfaction. Consequently, the coach's motivational climate implications are discussed in light of its implications for the quality and potential maintenance of sports participation among athletes(57).

Simultaneously, Curran et al.(58) examined the mastery climate (emphasis on effort and learning) and performance climate (emphasis on ability and outcome) in adolescent soccer players; at the end of the research, the authors reported that a mastery climate positively predicted all dimensions of engagement. Besides, the cognitive aspects of engagement were positively predicted by climate performance. These same researchers concluded that a mastery climate offers a means to promote higher levels of overall participation(58).

Also, Møllerløkken et al.(56) directly compare players' and coaches' perceptions of their respective teams' motivational climate. At the end of the study, the researchers noted that players of both sexes perceived the motivational climate to be significantly more performance-oriented and significantly less dominance-oriented than coaches, concluding that understanding player motivation is important to the persistence interruption of the sport. As observed, both the motivational climate and the orientation of sports practice condition the participation or abandonment of the sports practice $(20,56)$. In turn, coaches' motivational strategies should be reviewed, as there is sometimes a mismatch between the motivational strategies used and those perceived by young people in $\operatorname{sport}^{(56)}$.

\section{Impact of physical habits on obesity}

Evidence shows a more significant presence of positive emotions in normal-weight students; negative emotions are mostly present in students with overweight or obesity problems(37). Specifically, it has been described that there is a relationship between the presence of obesity and negative emotional states, such as high levels of anxiety, depression, lack of satisfaction in body image, and low

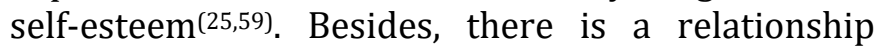
between obesity and psycho-emotional discomfort, conditioning the satisfaction level in life(60). In this context, it is clear that there is an urgent need to educate these aspects to a society that repeats unhealthy behaviors ${ }^{6}$ ). Therefore, the problem is the person who suffers from obesity and a whole social nucleus that does not have these healthy habits rooted(61,62).

This fact demonstrates that the human being develops learning by imitation; therefore, it is extremely important to consider the adolescent and his whole environment ${ }^{(15)}$. As already mentioned, the quality of life is conditioned by several factors; in this sense, food regulation and commercialization define the availability and accessibility that families have to these products ${ }^{(1)}$. Therefore, if the consumption of ultra-processed foods generates increased body weight, body mass index (BMI), and abdominal perimeter(2), it may also generate negative emotions in students(37). In turn, social and cultural norms, including the built environment in cities, condition the level of physical activity of the population(1), in turn, environmental barriers influence the physical activity behavior of the school population(3). In this sense, some research has pointed out that sports facilities that are often insufficient and precarious for the practice of physical exercise and sport(63).

When mentioning the factors that condition the levels of overweight and obesity in children, and by association the quality of life and the children's emotions, the family environment stands out as one of the main responsible(1). In this sense, the family has an essential role in the formation of a person(5). Research by Latorre et al.(63) concluded that most 
parents initiate their children into sports for the health, education, fun, and socialization that comes with playing sports. The same researchers mention that parents are important enough to create the right habits(63).

As it has been observed, there is an association between abnormal anthropometric parameters with adverse effects on emotions(37). It has also been determined that low levels of physical activity are a priority factor in the development of overweight and obesity(2). Likewise, it has been reported that parents are the primary agents in creating the habits of physical activity, physical exercise, and sport(63). Therefore, all these factors condition the quality of life of the child population. These factors should be considered in governmental policies globally; it has been demonstrated that children manage to perceive environmental barriers (physical, social, institutional) as agents that affect their physical activity levels(3).

\section{Socio-emotional support on experienced affectivity, self-confidence, and self-efficacy in young people}

It has been demonstrated that adolescents configure their personalities through their emotional experiences in the family, school, and society that most affect their development(64). However, educational practice has hardly valued the importance of affectivity in acquiring an integral formation ${ }^{65)}$. Considering that education must be oriented to the full development of the student's personality, cognitive development must be complemented by emotional development(31). In this emotional development, the family and the coach have a fundamental role, finding a good correlation between the favorable climate, the support in the autonomy, and the emotional development $(r=0.55$ and $r=0.36$, respectively)(30). Besides, these safe and positive social models encourage more resources and skills for decision making and problem-solving(66) and better manage stressful situations ${ }^{67}$. This leads to young people developing holistically, with cognitive, physical, and emotional education(27).

\section{Different achievement goals according to age and gender}

Evidence shows that there are more significant positive effects in the study groups 10-12 and 15-17 years old when the assigned activities are related to the task and friendship approach. In turn, the group of 13-14 years old presents positive effects in the approach and avoidance of the task, while in the range 10-12 and 15-17 years old there are adverse effects in the approach to the task; finally, in the ranges 13-14 years old the most significant adverse effects are presented by the approach of friendship(36). On the other hand, several researchers have shown that men are continually comparing improvements among pairs, more than women $(23,59,68)$. However, there are contrasts with other studies in which Korean students from the age of 12 onwards adopted greater affection in the approach-performance goals(69). This information allows us to observe how the socio-cultural context directly influences the students' adoption goals ${ }^{(68)}$.

\section{Limitations and perspectives}

Undoubtedly, a systematic review including three articles does not allow us to generalize the results. However, this scant evidence analyzing the influence of affectivity on school children and adolescents' physical habits is an indicator of two conditions. On the one hand, despite the evidence showing the importance of physical activity, physical exercise, and sports in people, the influence of the environment on school children and adolescents' physical habits has not been assessed. On the other hand, the adult population, unaware of this influence, generates a vicious circle that triggers sedentary adults with low quality of life. We believe that this study contributes to future research on affectivity as a determining factor in the acquisition of physical habits in children and adolescents.

\section{Conclusions}

At the end of the systematic review, it was shown that there is a significant influence of affectivity on adolescents' physical habits. Also, it could be observed that this influence, whether positive or negative, will directly influence adolescents' interest in physical activity and sports, conditioning their adherence to sports practice in adulthood.

Although there are positive and negative affective situations throughout life, adolescents must have the necessary tools to face various situations of fear, surprise, anger, joy, and sadness that may arise. These situations can be better addressed if adolescents have a network of constant social-emotional support, mainly family, teachers, coaches, and friends. Likewise, if these interactions are correct, they generate in the student greater self-esteem and selfconfidence. 
Finally, although they are not the main factor, it is also crucial that there are physical spaces that encourage adherence to these practices for the incorporation of physical activity habits. The spaces designed for the practice of physical activity should be in all environments of children and adolescents (schools, squares, recreation centers, among others).

\section{Practical Applications}

In practical terms and after conducting the systematic review, we recommend taking the following considerations to generate greater adherence to physical habits:

- Physical Education teachers should consider the diversity of each student's characteristics, thus developing activities that generate class's enjoyment and encourage the development of a positive attitude, generating an integral development in their personality.

- Physical Education teachers must integrate the entire educational community to promote physical and healthy habits, including directors, parents, and guardians.

- Coaches must consider athletes' autonomy, which will provide tools for developing their selfesteem and self-confidence, increasing their ability to overcome any adversity.

Funding: The authors declare no funding sources.

Conflict of interests: None declared by the authors.

\section{References}

1. Malo-Serrano M, Castillo N, Pajita D. La obesidad en el mundo. An La Fac Med/ [Internet]. 2017;78(2):173-8. DOI: 10.15381/anales.v78i2.13213.

2. Lozano Aguilar VM, Hermoza-Moquillaza RV, ArellanoSacramento C, Hermoza-Moquillaza VH. Relación entre ingesta de alimentos ultra procesados y los parámetros antropométricos en escolares. Rev Medica Hered [Internet]. 2019;3068-75. DOI: 10.20453/rmh.v30i2.3545.

3. Álvarez Bogantes C, Villalobos Viquez G, Vargas Tenorio J. Determinación de la actividad física en el recreo escolar: combinando mediciones de actividad física y la perspectiva estudiantil. Rev Ciencias Mov Hum Salud [Internet]. 2018;14(2):36-48. DOI: 10.15359/mhs.14-2.4.

4. Leiva AM, Martínez MA, Cristi-Montero C, Salas C, RamírezCampillo R, Díaz X, et al. El sedentarismo se asocia a un incremento de factores de riesgo cardiovascular $y$ metabólicos independiente de los niveles de actividad física. Rev Med Chil [Internet]. 2017;145(4):458-67. DOI: 10.4067/S0034-98872017000400006.

5. Ramos Rangel Y, González Váldes $M$ de los A. Un acercamiento a la función educativa de la familia. Rev Cuba
Med Gen Integr [Internet]. 2017;33(1):100-14. Disponible en:

http://www.revmgi.sld.cu/index.php/mgi/article/view/25 $8 / 127$

6. Chile G. Resumen Ejecutivo “Encuesta Nacional de Hábitos de Actividad Física y Deporte 2018 en Población de 18 años y más." Ministerio Del Deporte. 2018;1-59.

7. Bossay Salinas C. Sports Culture in Chile, Meta-Analysis on Physical Activity and Sports Habits 2006-2018. Rev Iberoam Ciencias Act Fis Deport [Internet]. 2020;9(1):64-74. DOI: 10.24310/riccafd.2020.v9i1.8302.

8. OECD Reviews of Public Health. Chile: OECD Rev Public Heal Chile; 2019. DOI: 10.1787/9789264309593-en.

9. Atalah E. Epidemiología de la obesidad en chile. Rev Médica Clínica Las Condes [Internet]. 2012;23(2):117-23. DOI: 10.1016/s0716-8640(12)70287-0.

10. Bjerregaard LG, Adelborg K, Baker JL. Change in body mass index from childhood onwards and risk of adult cardiovascular disease. Trends Cardiovasc Med [Internet]. 2020;30(1):39-45. DOI: 10.1016/j.tcm.2019.01.011.

11. Jakicic JM, Powell KE, Campbell WW, Dipietro L, Pate RR, Pescatello LS, et al. Physical activity and the prevention of weight gain in adults: a systematic review. Med Sci Sports Exerc [Internet]. 2019;51(6):1262-9. DOI: 10.1249/MSS.0000000000001938.

12. Recomendaciones mundiales sobre actividad fisica para la salud [Internet]. OMS; 2012. Disponible en: https://www.paho.org/es/noticias/9-5-2012recomendaciones-mundiales-sobre-actividad-fisica-parasalud

13. Gobierno de Chile. Encuesta nacional de salud 2016-2017 primeros resultados. Santiago: MINSAL; 2017. p. 1-61. Disponible en: https://www.minsal.cl/wpcontent/uploads/2017/11/ENS-2016-17_PRIMEROSRESULTADOS.pdf

14. Díaz-Martínez X, Petermann F, Leiva AM, Garrido-Méndez A, Salas-Bravo C, Martínez MA, et al. No cumplir con las recomendaciones de actividad física se asocia a mayores niveles de obesidad, diabetes, hipertensión y síndrome metabólico en población chilena. Rev Med Chil [Internet]. 2018;146(5):585-95. DOI: $\quad 10.4067 / \mathrm{s} 0034-$ 98872018000500585.

15. Soler-Lanagrán A, Castañeda Vázquez C. Estilo de vida sedentario y consecuencias en la salud de los niños. Una revisión sobre el estado de la cuestión. J Sport Heal Res [Internet]. 2017;9(2):187-98. Disponible en: https://idus.us.es/handle/11441/63685

16. Telzer EH, van Hoorn J, Rogers CR, Do KT. Social influence on positive youth development: a developmental neuroscience perspective. Adv Child Dev Behav [Internet]. 2018;54:21558. DOI: 10.1016/bs.acdb.2017.10.003.

17. Marques A, González Valeiro $M$, Martins J, FernándezVillarino MA, Carreiro da Costa F. Relación entre la actividad física de los adolescentes y la de madres/padres. Rev Psicol Del Deport [Internet]. 2017;26(1):145-55.

18. Jowett S. Coaching effectiveness: the coach-athlete relationship at its heart. Curr Opin Psychol [Internet]. 2017;16:154-8. DOI: 10.1016/j.copsyc.2017.05.006.

19. Gómez-López M, Borrego CC, da Silva CM, Granero-Gallegos A, González-Hernández J. Effects of motivational climate on fear of failure and anxiety in teen handball players. Int $J$ Environ Res Public Health [Internet]. 2020;17(2):592. DOI: 10.3390/ijerph17020592.

20. Sánchez M, Sánchez-Sánchez J, Carcedo RJ, García JA. Clima, orientación motivacional y diversión en futbolistas alevines. 
Rev Int Med Ciencias Act Fis Deport [Internet]. 2020;20(79):507-20. DOI: 10.15366/rimcafd2020.79.008.

21. León MP, Prieto-Ayuso A, Gil-Madrona P. Hábitos y motivos de ejercicio físico en estudiantes universitarios y su relación con el valor otorgado a la Educación Física. Retos [Internet]. 2020;3778-84. DOI: 10.47197/retos.v37i37.70454.

22. Vallerand R. On Passion for life activities: The dualistic model of passion. Adv Exp Soc Psychology [Internet]. 2010;42:97193. DOI: $10.1016 / S 0065-2601(10) 42003-1$.

23. Sandín B. Escalas Panas de afecto positivo y negativo para niños y adolescentes (PANASN). Rev Psicopatología Psicol Clínica [Internet]. 2003;8(2):173-82. DOI: 10.5944/rppc.vol.8.num.2.2003.3953.

24. Dale LP, Vanderloo L, Moore S, Faulkner G. Physical activity and depression, anxiety, and self-esteem in children and youth: An umbrella systematic review. Ment Health Phys Act [Internet]. 2019;16:66-79. DOI: 10.1016/j.mhpa.2018.12.001.

25. Gil-Madrona P, Martínez-López M. Emociones percibidas, por alumnos y maestros, en educación física en $60^{\circ}$ curso de primaria. Educ XX1 [Internet]. 2016;19(2):179-204. DOI: 10.5944/educXX1.14230.

26. Lundqvist C, Kenttä G, Raglin J. Directional anxiety responses in elite and sub-elite young athletes: intensity of anxiety symptoms matters. Med Sci Sport [Internet]. 2011;21(6):853-62. DOI: $10.1111 /$ j.16000838.2010.01102.x.

27. Pellicer Royo I. Educación Física emocional: De la teoría a la práctica. 2da ed. Barcelona; 2018. Disponible en: https://www.inde.com/es/productos/detail/pro_id/143

28. Bisquerra Alzina R. Educación Emocional y Competencias Básicas para la Vida. Rev Investig Educ [Internet]. 2003;21(1):7-43. Disponible https://revistas.um.es/rie/article/view/99071

29. Alasmari HD, Al-Shehri AD, Aljuaid TA, Alzaidi BA, Alswat KA. Relationship between body mass index and obesity awareness in school students. J Clin Med Res [Internet]. 2017;9(6):520-4. DOI: 10.14740/jocmr2987w.

30. Molina López VM, Oriol Granado X, Mendoza Lira MC, Malo Cerrato S. Influencia del apoyo socioemocional sobre la afectividad experimentada, autoconfianza y autoeficacia en jovenes deportistas. Rev Psicol Del Deport [Internet]. 2018;27(1):51-8. Disponible en: https://archives.rpdonline.com/article/view/v27-n1-molina-lopez-orioletal.html

31. Durlak J, Weissberg R, Dymnicky A, Taylor R, Schellinger K. El impacto de mejorar el aprendizaje social y emocional de los estudiantes: un metaanálisis de intervenciones universales basadas en la escuela. Child Dev [Internet]. 2011;82(1):405-32. DOI: $\quad$ 10.1111/j.14678624.2010.01564.x.

32. Morano M, Colella D, Capranica L. Body image, perceived and actual physical abilities in normal-weight and overweight boys involved in individual and team sports. J Sports Sci [Internet]. 2011;29(4):355-62. DOI: 10.1080/02640414.2010.530678.

33. Moher D, Shamseer L, Clarke M, Ghersi D, Liberati A, Petticrew M, et al. Evaluation of ASTM standard test method E2177: retroreflectivity of pavement markings in condition of wetness. Transp Res Rec [Internet]. 2012;2272(1):87-93. DOI: $10.3141 / 2272-10$.

34. Maher CG, Sherrington C, Herbert RD, Moseley AM, Elkins M. Reliability of the PEDro Scale for Rating Quality of Randomized Controlled Trials. Phys Ther [Internet]. 2003;83(8):713-21. DOI: 10.1093/ptj/83.8.713.
35. De Morton NA. The PEDro scale is a valid measure of the methodological quality of clinical trials: a demographic study. Aust J Physiother [Internet]. 2009;55(2):129-33. DOI: 10.1016/S0004-9514(09)70043-1.

36. Gil-Madrona P, Cejudo J, Martinez-Gonzalez JM, LopezSanchez GF. Impact of the body mass index on affective development in physical education. Sustainability [Internet]. 2019;11(9):2459. DOI: 10.3390/su11092459.

37. Méndez-Giménez A, Garcia-Romero C, Cecchini-Estrada JA. $3 \times 2$ Achievement goals, friendship and affectivity in physical education: age-gender differences. Rev Int Med Ciencias Act Fis Deport [Internet]. 2018;18(72):637-53. DOI: 10.15366/rimcafd2018.72.003.

38. López Sánchez F, Etxebarria I, Fuentes Rebollo MJ, Ortiz MJ. Desarrollo afectivo y social. Madrid, España: Ediciones Pirámide; 2014. Disponible en: https://www.edicionespiramide.es/libro.php?id=3438504

39. Willis J, Willis M. Research-based strategies to ignite student learning: insights from neuroscience and the classroom. 2nd ed. Association for Supervision and Curriculum Development; 2020. Disponible en: https://www.ascd.org/books/research-based-strategies-toignite-student-learning-insights-from-neuroscience-andthe-classroom-revised-and-expandededition?variant=120029

40. Nayir F. The relationship between student motivation and class engagement levels. Eurasian J Educ Res [Internet]. 2017;17(71):59-78. Disponible en: https://files.eric.ed.gov/fulltext/EJ1158398.pdf

41. Wang Y, Qiao D, Chui E. Student engagement matters: a selfdetermination perspective on chinese MSW students' perceived competence after practice learning. Br J Soc Work [Internet]. 2018;48(3):787-807. DOI: 10.1093/bjsw/bcx015.

42. Weber M, Wagner L, Ruch W. Positive feelings at school: on the relationships between students' character strengths, school-related affect, and school functioning. J Happiness Stud [Internet]. 2016;17(1):341-55. DOI: 10.1007/s10902014-9597-1.

43. Gallagher KM, Jones TR, Landrosh NV, Abraham SP, Gillum DR. College Students' Perceptions of Stress and Coping Mechanisms. J Educ Dev [Internet]. 2019;3(2):25-34. DOI: 10.20849/jed.v3i2.600.

44. Maeda J. Self-Efficacy Reduces Impediments to Classroom Discussion for International Students: Fear, Embarrassment, Social Isolation, Judgment, and Discrimination. IAFOR J Educ [Internet]. 2017;5(2):141-59. DOI: 10.22492/ije.5.2.07.

45. Schiefele U. Classroom management and mastery-oriented instruction as mediators of the effects of teacher motivation on student motivation. Teach Teach Educ [Internet]. 2017;64:115-26. DOI: 10.1016/j.tate.2017.02.004.

46. Agricola BT, Prins FJ, Sluijsmans DMA. Impact of feedback request forms and verbal feedback on higher education students' feedback perception, self-efficacy, and motivation. Assess Educ Princ Policy Pract [Internet]. 2020;27(1):6-25. DOI: 10.1080/0969594X.2019.1688764.

47. Lester KJ, Lisk SC, Carr E, Patrick F, Eley TC. Associations between attentional bias and interpretation bias and change in school concerns and anxiety symptoms during the transition from primary to secondary school. J Abnorm Child Psychol [Internet]. 2019;47(9):1521-32. DOI: 10.1007/s10802-019-00528-3.

48. Huang P-S, Liu C-H, Chen H-C, Sommers S. Attentional bias of students toward negative feedback in bad outcome situations: the mechanism of self-defense. Soc Psychol Educ 
[Internet]. 2018;21(3):565-83. DOI: 10.1007/s11218-0189429-y.

49. Barrett LF, Lewis M, Haviland-Jones JM. Handbook of emotions. 4th ed. New York: Guilford Publications; 2016. Disponible

en: https://www.guilford.com/books/Handbook-of-

Emotions/Barrett-Lewis-Haviland-Jones/9781462536368

50. Kennes A, Peeters S, Janssens M, Reijnders J, Lataster J, Jacobs N. Psychometric evaluation of the mental health continuumshort form (MHC-SF) for dutch adolescents. J Child Fam Stud [Internet]. 2020;29(11):3276-86. DOI: 10.1007/s10826020-01803-4.

51. Vani MF, Pila E, Willson E, Sabiston CM. Body-related embarrassment: The overlooked self-conscious emotion. Body Image [Internet]. 2020;32:14-23. DOI: 10.1016/j.bodyim.2019.10.007.

52. Yli-Piipari S, Watt A, Jaakkola T, Liukkonen J, Nurmi J-E. Relationships between physical education students' motivational profiles, enjoyment, state anxiety, and selfreported physical activity. J Sport Sci Med [Internet]. 2009;8(3):327-36. Disponible

https://pubmed.ncbi.nlm.nih.gov/24149994/

53. Korpershoek H, Harms T, de Boer H, van Kuijk M, Doolaard S. A Meta-Analysis of the Effects of Classroom Management Strategies and Classroom Management Programs on Students' Academic, Behavioral, Emotional, and Motivational Outcomes. Rev Educ Res [Internet]. 2016;86(3):643-80. DOI: 10.3102/0034654315626799.

54. Gnepp J, Klayman J, Williamson IO, Barlas S. The future of feedback: Motivating performance improvement through future-focused feedback. PLoS One [Internet]. 2020;15(6):e0234444. DOI: 10.1371/journal.pone.0234444.

55. Freedberg M, Glass B, Filoteo JV, Hazeltine E, Maddox WT. Comparing the effects of positive and negative feedback in information-integration category learning. Mem Cogn [Internet]. 2017;45(1):12-25. DOI: 10.3758/s13421-0160638-3.

56. Møllerløkken NE, Lorås H, Pedersen AV. A comparison of players' and coaches' perceptions of the coach-created motivational climate within youth soccer teams. Front Psychol [Internet]. 2017;8:109. DOI: 10.3389/fpsyg.2017.00109.

57. Ruiz MC, Robazza C, Tolvanen A, Haapanen S, Duda JL. Coachcreated motivational climate and athletes' adaptation to psychological stress: Temporal motivation-emotion interplay. Front Psychol [Internet]. 2019;10:617. DOI: 10.3389/fpsyg.2019.00617.

58. Curran T, Hill AP, Hall HK, Jowett GE. Relationships between the coach-created motivational climate and athlete engagement in youth sport. J Sport Exerc Psychol [Internet]. 2015;37(2):193-8. DOI: 10.1123/jsep.2014-0203.

59. Duran C, Lavega P, Salas C, Tamarit M, Invernó J. Emotional physical education in adolescents. Identifying predictors of emotional experience. Cultura Ciencia Deporte [Internet]. 2015;10(28):5-18. DOI: 10.12800/ccd.v10i28.511.

60. Salas MI, Gattas V, Ceballos X, Burrows R. Tratamiento integral de la obesidad infantil: Efecto de una intervención psicológica. Rev Med Chil [Internet]. 2010;138(10):1217-25. DOI: $10.4067 /$ s0034-98872010001100002.

61. Biro FM, Wien M. Childhood obesity and adult morbidities. Am J Clin Nutr [Internet]. 2010;91(5):1499S-1505S. DOI: 10.3945/ajcn.2010.28701B.

62. Donnelly JE, Blair SN, Jakicic JM, Manore MM, Rankin JW, Smith BK. Appropriate physical activity intervention strategies for weight loss and prevention of weight regain for adults. Med Sci Sports Exerc [Internet]. 2009;41(2):459-71. DOI: 10.1249/MSS.0b013e3181949333.

63. Latorre P, Gasco F, García M, Martínez R, Quevedo O, Carmona F, et al. Analysis of the Influence of the Parents in the sports promotion of the children. J Sport Heal Res [Internet]. 2009;1(1):12-25. Disponible en: http://www.journalshr.com/papers/Vol\%201_N\%201/full. pdf

64. González González E. Desarrollo en la adolescencia: desarrollo social y moral, problemática en el desarrolllo de esta etapa. En: González E, Bueno J, editores. Psicología de la educación y del desarrollo en la edad escolar. España: CCS; 2004. p. 393-440. Disponible en: https://dialnet.unirioja.es/servlet/articulo? codigo=837875

65. Franco Royo T. Vida afectiva y educación infantil. Madrid, España: Digitalia Hispánica; 2016. Disponible en: https://www.digitaliapublishing.com/a/29121/vidaafectiva-y-educacion-infantil

66. Scharf M, Mayseless O, Kivenson-Baron I. Adolescents' attachment representations and developmental tasks in emerging adulthood. Dev Psychol [Internet]. 2004;40(3):430-44. DOI: 10.1037/0012-1649.40.3.430.

67. Seiffge-Krenke I, Beyers W. Coping trajectories from adolescence to young adulthood: Links to attachment state of mind. Res Adolesc [Internet]. 2005;15(4):561-82. DOI: 10.1111/j.1532-7795.2005.00111.x.

68. Dekker S, Krabbendam L, Lee N, Boschloo A, de Groot R, Jolles J. Sex differences in goal orientation in adolescents aged 10 19: The older boys adopt work-avoidant goals twice as often as girls. Learn Individ Differ [Internet]. 2013;26:196-200. DOI: 10.1016/j.lindif.2012.07.011.

69. Bong M. Age-related differences in achievement goal differentiation. Educ Psychol [Internet]. 2009;101(4):87996. DOI: $10.1037 / \mathrm{a} 0015945$. 